\title{
O DIREITO FUNDAMENTAL À SAÚDE E O PODER JUDICIÁRIO: QUANDO O SUS DEVE FORNECER "O REMÉDIO MAIS CARO DO MUNDO"
}

\author{
THE FUNDAMENTAL RIGHT TO HEALTH AND THE JUDICIARY: WHEN THE \\ PUBLIC HEALTH SYSTEM SHOULD PROVIDE "THE MOST EXPENSIVE MEDICINE \\ OF THE WORLD"
}

\begin{abstract}
Alessandra Garcia Marques
Mestra em Direito Constitucional pelo IDP. Graduada em História pela Universidade Federal de Uberlândia. Graduada em Direito pela Universidade Federal de Uberlândia. Pós-graduada em Direito Sanitário pela UNB, em Direito Tributário pela UCAM e em Direito Penal e Processual Penal pela UCAM. Atualmente é Promotora de Justiça titular da Promotoria de Justiça de Defesa do Consumidor do Ministério Público do Estado do

Acre. Ministra cursos de Direito do Consumidor na Escola da Magistratura do Acre ESMAC. Ministra curso na Escola Nacional de Defesa do Consumidor do Ministério da Justiça - ENDC.E-mail:amarques@mpac.mp.br
\end{abstract}

Recebido em: 20/04/2017

Aprovado em: 28/09/2017

RESUMO: O presente artigo pretende apreciar uma emblemática decisão judicial concessiva de antecipação de tutela proferida pela Justiça Federal no estado do Acre, que obrigou a União a fornecer medicamento a um paciente do Sistema Único de Saúde não produzido no Brasil, sem propósito curativo e sem registro na Anvisa, cujo custo anual para o ente público é atualmente superior a um milhão e duzentos mil reais. Foi para tanto utilizada como apoio a Metodologia de Análise de Decisões, embora se esteja tratando da análise de uma decisão apenas. Após a realização de uma pesquisa exploratória sobre os temas referentes ao fornecimento de medicamentos pelo Estado brasileiro e o ativismo ou protagonismo judicial, oportunidade em que foi consultada uma bibliografia básica sobre o tema deste trabalho, foi identificada uma questãoproblema, de forma que, feitos os recortes objetivo e institucional necessários, buscou-se produzir uma explicação do sentido da decisão a partir da interpretação realizada sobre o processo decisório, sobre a forma da decisão e sobre os argumentos produzidos. Ao final, foi possível identificar que a decisão apreciada é uma decisão que evidencia um protagonismo judicial, estando ela caracterizada pela aplicação direta da norma jurídica prevista na Constituição da República, quando também foi desprezado o fato de que existe política pública sobre o fornecimento de medicamentos especializados.

Palavras chave: Ativismo judicial. Direito à saúde. Integralidade. Sistema Único de Saúde.

ABSTRACT: This article intends to analyze an emblematic judicial decision given by the federal court in the state of Acre when the union was forced to give medicine to the patient of national health system not produced in brazil without the purpose of healing and without registration in Anvisa, whose annual cost to the public entity exceeds four hundred thousand dollars actually. It was used as support in this case the decision analysis methodology, although one decision has been analysed. After conducting an exploratory research on the issues related to the supply of medicines by the brazilian state and the judicial activism when was identified a basic bibliography about the subject of this work, then a question-problem was identified, so that it was made an objective and institutional cutting. This work intends to produce an explication about the 
sense of decision from the interpretation made on decision making, about the form of decision and its arguments. In the end, it was possible to identify that the decision is a decision that evidences a judicial role, being characterized by the direct application of the legal norm established in the Constitution of the Republic, when it was also neglected the fact that there is public policy on the supply of specialized medicines.

Keywords: Judicial Activism. Right to health. Integrality. National Health System (BR).

\section{INTRODUÇÃO}

A extensa descrição de direitos fundamentais contida na Constituição da República de 1988, na qual se incluem os direitos que exigem do estado prestação positiva, deixa evidente a opção da sociedade brasileira por um modelo de estado social.

Sucede que à previsão no texto da Constituição de um vasto rol de direitos sociais dentre os quais temos o direito à saúde, do qual decorre a norma jurídica da integralidade do atendimento em saúde, seguiu-se a inação ou a incapacidade do Estado brasileiro de satisfazer as expectativas socialmente criadas pelo legislador constituinte. Isso, dentro do modelo de tripartição do poder que foi explicitado no texto constitucional, tem feito com que cada vez mais o Poder Judiciário passe a ser provocado a decidir a respeito de tais direitos, pronunciando-se quanto ao âmbito de proteção, aos limites e às restrições das normas jusfundamentais que sobre os direitos sociais versam.

E, nesse sentido, no que diz respeito ao direito à saúde, reconhecido enquanto direito de forma universal, integral e gratuita, a avalanche de ações, sobretudo individuais, tem chamado a atenção de todos os que estudam o papel do Judiciário na ordem constitucional vigente. À míngua de bons serviços e ações de saúde ofertados pelo Sistema Único de Saúde, esculpidos na Constituição como de relevância pública, o Judiciário tem sido convocado a decidir sobre o fornecimento de medicamentos constantes ou não constantes nas listas de medicamentos oficiais estabelecidas pelo Estado, sobre a determinação de internação em unidades de terapia intensiva, sobre o fornecimento de tratamento fora do domicílio, sobre a prestação de serviço de transporte em unidade de terapia intensiva aérea, etc.

Não raramente, ademais, o Judiciário tem sido chamado a decidir sobre o fornecimento de medicamentos e/ou tratamentos de alto custo, alguns fora do país, outros experimentais, sobre o pagamento de fraldas, e de transporte para os pacientes que deve ser realizado fora do domicílio, etc. ${ }^{1}$ Isso sem nos esquecermos de condenações ao fornecimento de sabão de coco em pó, escova de dente, antisséptico bucal, xampu anticaspa, pilhas, copos descartáveis, chupetas, papel toalha, creme fixador de dentaduras, filtros de água, óleo de soja, creme de leite, fubá, amido de milho, farinha láctea, etc. ${ }^{2}$

Nesse momento, já devemos anunciar que judicialização (da saúde, no caso em evidência neste trabalho) não se confunde com ativismo judicial, termo a respeito do qual adiante trataremos, sendo evidente que aquela decorre, por exemplo, muito naturalmente do modelo de

\footnotetext{
${ }^{1}$ O número de pacientes que entraram na Justiça contra o Sistema Único de Saúde (SUS) na capital paulista na busca por tratamentos ou medicamentos não oferecidos na rede pública cresceu $32 \%$ em três anos, segundo dados obtidos pelo jornal o Estado de S. Paulo com o Tribunal de Justiça de São Paulo (TJ-SP). Em 2010, foram ajuizadas 1514 ações nas varas da cidade responsáveis por receber pedidos de procedimentos médico-hospitalares ou remédios. Em 2013, o número de processos do tipo passou para 2011, uma média de uma nova ação a cada quatro horas. Estão incluídos nesses números pedidos de remédios ou terapias ainda não disponíveis no Brasil ou na rede pública ou mesmo procedimentos que são cobertos pelo SUS mas que, por indisponibilidade momentânea ou longas filas de espera, demoram a ser oferecidos. (Disponível em: <http://veja.abril.com.br/noticia/saude/sp-acoes-na-justica-contrao-sus-crescem-32-em-3-anos/>. Acesso em: 13/07/2015)

${ }^{2}$ Informação contida em extensa matéria jornalística feita pela Revista Época no ano de 2012.Disponível em http://revistaepoca.globo.com/tempo/noticia/2012/03/o-paciente-de-r-800-mil.html.Acesso em 11 de julho de 2015.
}

Revista de Direito Brasileira | São Paulo, SP | v. 20 | n. 8 | p. 104-127 |Mai./Ago. 2018 
tripartição de poderes esculpido na Constituição de 1988, assunto que também será abordado à frente.

Já quanto ao protagonismo ou ativismo do Judiciário - num contexto de judicialização da saúde - verificável em decisões que versam sobre a definição do âmbito de proteção, dos limites e restrições das normas jusfundamentais que tratam do direito à saúde e da integralidade na assistência à saúde, as opiniões especializadas seguem sendo divergentes.

É possível, nesse caminho, constatarmos uma atuação ativista dos juízes na área da saúde ou talvez fosse melhor dizermos, no contexto constitucional brasileiro, um protagonismo do Judiciário, a partir da presença de diversos fatores no texto da Constituição da República que possibilitam o ativismo judicial, que permitem uma atuação desinibida do juiz, assunto a respeito do qual, aliás, trataremos adiante, ao realizarmos a análise propriamente da decisão judicial escolhida.

Podemos encontrar, também, aqueles que defendem uma postura de autocontenção do Judiciário, porquanto as decisões judiciais sobre a saúde pública desorganizam o orçamento público, já desgastado originalmente pelo modo como vem sendo tratado até mesmo pelos Poderes Legislativo e Executivo, fazendo com que o sistema público de saúde torne-se menos justo e menos racional (WANG, 2013).

E é possível, além disso, introduzirmos ao tema o argumento referente à aplicação do princípio da reserva do financeiramente possível, o que, dentre todos os argumentos contrários à judicialização da saúde e à atuação ativista dos juízes, parece ser o mais inapropriado, embora a esse respeito o presente trabalho não pretenda tratar.

Não podemos deixar de mencionar que diversos outros argumentos têm sido levantados ora para defender ora para rechaçar a atuação ativista do Judiciário, quando está em jogo o direito à saúde.

A respeito propriamente da judicialização da saúde no país, Asensi (2013) afirma que as decisões judiciais podem apresentar importantes resultados na efetivação desse direito fundamental, embora aponte o autor que, para tanto, possui o Judiciário desafios internos a serem enfrentados no processamento e julgamento de demandas sobre saúde pública.

E diz Asensi (2013, on line) serem estes os ditos desafios do Judiciário:

a) a predominância de ações judiciais de feição individual nos diversos tribunais brasileiros, inclusive na seara da saúde; b) a incipiente utilização de mecanismos extrajudiciais - a exemplo da arbitragem, auto-composição, etc -, exceto quando desenvolvidos pelas demais instituições jurídicas; c) a colonização por um perfil de classe média e classe média alta na judicialização, especialmente em municípios em que a Defensoria Pública não se encontra bem estruturada; d) a reprodução de uma visão medicalizada da saúde também pode ocorrer, principalmente com a sobrevalorização do saber médico e farmacêutico no processo decisório judicial; e) se comparado aos Conselhos e Conferências, o Judiciário pode ser visto pelos cidadãos como uma estratégia mais rápida, menos custosa e que requer menos esforços físicos e psicológicos em matéria de saúde; f) a decisão judicial pode produzir um impacto financeiro e orçamentário significativo, especialmente para pequenos municípios; g) a predominância da dimensão curativa na judicialização, que versa sobre a concessão de medicamentos, deferimento de exames, etc, em detrimento da dimensão preventiva.

É, nesse contexto, portanto, que no presente artigo objetivamos analisar uma decisão judicial, dentre tantas outras que estão sendo produzidas diariamente no Brasil sobre o direito à saúde e o sistema público de saúde, a fim de compreendermos a argumentação dela constante e o papel Judiciário naquele caso concreto, e, assim, podermos, partindo do caso particular, 
entendermos um viés da judicialização da saúde no Brasil e, mais do que isso, do ativismo ou, melhor dizendo, do protagonismo judicial.

Importa, ainda assim, evidenciar que, em que pese neste trabalho se esteja no contexto da judicialização da saúde, não se pode olvidar de que a concretização desse direito humano e fundamental também deva passar e vem passando cada vez mais pela solução de problemas fora do processo, denominada por Asensi (2003) de juridicização, ou seja, pela existência de espaços de solução desses problemas fora do âmbito do processo.

\section{A METODOLODIA UTILIZADA}

Optamos por analisar apenas uma decisão judicial, por razões que adiante serão devidamente demonstradas, utilizando como inspiração para tanto a Metodologia de Análise das Decisões desenvolvida por Freitas Filho e Lima (2010), que não se confunde com o Estudo de Caso e nem com a Análise de Jurisprudência, porquanto utiliza procedimentos distintos, sendo que os objetivos e ainda o instrumento teórico também não confundem.

Nesse sentido, de antemão é importante reforçarmos que não é pretensão do trabalho realizar Análise de Jurisprudência, a qual implica em coletar as decisões de um ou de diversos órgãos judiciais a respeito de um problema jurídico, objetivando compreender a posição daqueles que decidem sobre o problema e até suas possíveis inclinações (FREITAS FILHO e LIMA, 2010).

A Metodologia de Análise de Decisões, diferentemente disso, possibilita àquele que dela lança mão a organização das informações referentes às decisões proferidas num certo contexto, podendo constatar se existe coerência decisória no contexto que foi previamente estabelecido e, ainda, faz com que seja possível explicar o sentido das decisões, partindo da interpretação de seu processo decisório, da forma e dos argumentos que foram produzidos (FREITAS FILHO e LIMA, 2010).

É, todavia, necessário dizermos que, em que pese a utilização da Metodologia de Análise de Decisões adeque-se de modo mais consistente à análise de diversas decisões, como bem explicitam Freitas Filho e Lima (2010), não há impedimento à sua utilização quando estamos diante de uma só decisão, sendo a esse respeito relevante mencionarmos que:

Ao realizar a pesquisa exploratória, primeiro passo para a identificação do problema a ser investigado, o pesquisador elegerá seu foco de atenção. $\mathrm{O}$ segundo passo será realizar o recorte institucional e o recolhimento dos dados, expressos por decisões ou conjuntos de decisões. Após a seleção das decisões o pesquisador terá em mãos um determinado número delas e deverá organizá-las de forma a "tratar" os dados.

O resultado desse primeiro passo é a constituição de um banco de dados contendo decisões organizadas de forma criteriosa com base na relevância de pertença das decisões ao conjunto. No caso de decisão única deverá o pesquisador justificá-la, pois o método se presta prioritariamente a analisar um determinado processo decisório, aí compreendido o movimento no tempo de uma prática jurídica que encontra sentido justamente no fato de ser um modo de agir com um sentido passível de interpretação. É possível, entretanto, que o pesquisador veja em uma decisão colegiada, por exemplo, a expressão de várias decisões que expressam um determinado processo decisório. Não se pode excluir, portanto, a priori, a possibilidade de investigação sobre uma única decisão, embora o método seja mais propriamente aplicável a conjuntos decisórios. (FREITAS FILHO e LIMA, 2010, pp.12-13)

Dessa sorte, no caso de um estudioso pretender analisar uma decisão apenas, deverá tomar o cuidado de justificá-la, pois a Metodologia de Análise de Decisões ocupa-se 
propriamente da análise de um processo decisório, no qual se inclui o movimento ao longo de um tempo de uma prática jurídica que tem sentido precisamente porque constitui um modo de agir passível de interpretação (FREITAS FILHO e LIMA, 2010).

Assim, a Metodologia de Análise de Decisões no presente trabalho serve como norte, com a devida ressalva acima apontada, para o exame de uma decisão judicial apenas, que concedeu antecipação de tutela ao autor, num processo individual, obrigando a União a fornecer medicamento cujo custo, é bom evidenciarmos, ultrapassa a quantia de um milhão de reais ao ano para apenas um paciente portador de doença rara e grave.

\section{A ESCOLHA DA DECISÃO A SER ANALISADA}

É indispensável justificarmos a escolha de decisão judicial única para a presente análise. Em verdade, mesmo que saibamos que, uma vez ou outra, seja proferida uma ou outra decisão judicial inusitada a respeito do direito humano e fundamental à saúde, tal como quando se decide sobre a concessão de fraldas a pacientes do Sistema Único de Saúde, em ação individual ou até em ação coletiva ${ }^{3}$, não é sempre que verificamos decisões que obrigam o ente público a custear tratamento com medicamentos de alto custo ou, pior do que isso, até com o medicamento mais caro do mundo.

No caso em questão, a escolha da decisão a ser analisada decorre de um conjunto de elementos que, sem qualquer dúvida, vieram à tona a partir da perplexidade gerada por três questões fáticas, pois as jurídicas serão analisadas adiante, quando realizarmos o exame propriamente da decisão em tela: o medicamento pleiteado é qualificado pelo autor, pela literatura produzida ao seu respeito e pelo juiz que concedeu a antecipação de tutela como sendo o mais caro do mundo, sendo que seu fornecimento a somente um paciente custa, na atualidade, anualmente, mais de um milhão de reais aos cofres públicos; tal droga não tem registro na Anvisa e, por fim, o medicamento não tem finalidade curativa, estando apontado cientificamente como cura da doença apenas o transplante de medula óssea.

Trata o caso, assim, de uma demanda cível individual proposta perante a Justiça Federal em Rio Branco, no estado do Acre, por meio da qual o autor, que alegou ser portador de uma doença grave denominada Hemoglobinúria Paroxística Noturna - HPN, requereu medicamentos, dentre os quais o Eculizumabe/Soliris. Na inicial já constava a descrição da doença e de seus sintomas, indicando que o Soliris seria o único medicamento disponível para o tratamento da doença, e que não possui registro na Anvisa. Ademais, o autor aduziu que o medicamento, comercializado na Europa e nos Estados Unidos, onde teria registro no FDA - Food and Drug Administration, seria capaz de diminuir os sintomas, retardando o avanço da doença e evitando seus efeitos que levam os doentes à morte.

A decisão que antecipou a tutela, cujo exame é aqui pretendido, foi dada quando ainda estava em vigor no Código de Processo Civil de 1973, oportunidade em que foi deferido o pedido do autor, para que a União fornecesse o medicamento por ele requerido. E, a fim de melhor contextualizarmos o caso, importa mencionarmos que a inicial foi instruída somente com exames laboratoriais e simples relatório médico, segundo consta da interlocutória ora examinada, sendo que consta da inicial e da referida decisão interlocutória, repisemos, menção ao fato de que o medicamento pleiteado é o mais caro do mundo, podendo custar, atualmente, meio milhão de dólares por ano o tratamento com a referida droga para um paciente apenas.

\footnotetext{
${ }^{3}$ Recentemente, o Ministério Público Federal ajuizou ação civil pública no estado de Alagoas a fim de assegurar o fornecimento de fraldas geriátricas descartáveis a pacientes do Sistema Único de Saúde naquele ente federativo, porquanto as fraldas estariam equiparadas a materiais farmacêuticos, demanda coletiva essa na qual foram mencionados precedentes do STF, STJ e do Tribunal Regional Federal da $5^{\text {a }}$ região, podendo ser feita consulta processual pelo número: 0003240-57.2012.4.05.8000.
} 
Em sede de agravo de instrumento a decisão interlocutória analisada não foi modificada pelo Tribunal Regional Federal da $1^{\text {a }}$ Região, ao passo que na sentença os pedidos foram todos julgados improcedentes por outro magistrado, embora na dita sentença tenha ocorrido algo que não tem acolhimento no sistema jurídico processual brasileiro, exceto nas demandas que versam sobre a constitucionalidade das leis, e que foi denominado expressamente na sentença de modulação dos efeitos da decisão, para fazer com que a decisão interlocutória valesse pelo prazo de 4 (quatro) meses, contados da intimação da União a respeito da sentença, sob o argumento de que, nesse tempo, poderia o autor obter outra decisão judicial que lhe assegurasse a sua pretensão.

Portanto, embora no julgamento do mérito tenha sido negado o pedido do autor, por quatro meses ele deve receber o medicamento mais caro do mundo.

Aliás, é válido aduzirmos que, em 2012, cada vidro de 30 mililitros do Soliris custava mais de $\mathrm{R} \$ 11.000,00$ (onze mil reais), ao passo que, quinzenalmente, um dos pacientes que obteve vitória na justiça brasileira necessitava à época de três frascos. Desse modo, esse paciente, sozinho, custava, em 2012, R\$35.000,00 (trinta e cinco mil reais) a cada 15 dias e cerca de $\mathrm{R} \$$ 70.000,00 (setenta mil reais) por mês ao Sistema Único de Saúde. ${ }^{4}$

A respeito da Hemoglobinúria Paroxística Noturna - HPN, é bom que esclareçamos também, pode provocar trombose, AVC, infarto, etc. Trata-se na verdade de uma anemia crônica causada pela decomposição excessivamente rápida dos glóbulos vermelhos, que pode ser curada em metade dos pacientes com um transplante de medula óssea. O Soliris, que não a cura, reduz a destruição dos glóbulos vermelhos e sintomas do HPN apenas, mas não livra o paciente do risco de trombose, motivo pela qual deve também tomar anticoagulante ${ }^{5}$.

Resta evidente que a escolha da decisão interlocutória proferida pela Justiça Federal no estado do Acre está justificada pelo fato de que o Sistema Único de Saúde, por meio da indicada decisão, foi obrigado a custear medicamento importado de altíssimo custo, "o medicamento mais caro do mundo", a um paciente portador de doença rara, medicamento esse que não é produzido no Brasil, não tem registro na Anvisa, não consta de listas oficiais de medicamentos, e que, por fim, carece de propriedades curativas da enfermidade que acomete o autor da demanda beneficiado pela tratada interlocutória.

\section{A FUNDAMENTAÇÃO SOBRE DIREITO PROCESSUAL CONTIDA NA DECISÃO INTERLOCUTÓRIA ANALISADA}

Para analisarmos a decisão escolhida, é imperioso apontarmos, antes de tudo, o fato de que, ainda sob a égide do CPC de 1973, a antecipação de tutela contra o poder público contava basicamente com um microssistema próprio formado por regras específicas previstas em leis esparsas.

O novo Código de Processo Civil, aliás, poderia ter tratado integralmente da tutela provisória contra a fazenda pública, o que não ocorreu, sendo que foi somente no art. 1.059, que, de modo a simplificar o tratamento do tema, o CPC de 2015 expressamente estabeleceu que a tutela provisória, seja ela cautelar ou satisfativa, contra a fazenda pública deverá ser tratada pelos arts. $1^{\circ}$ a $4^{\circ}$ da Lei Federal n. $.^{\circ} 8.437 / 92$ e pelo art. $7^{\circ} \S 2^{\circ}$, da Lei Federal n. ${ }^{\circ} 12.016 / 2009$, ao

\footnotetext{
${ }^{4}$ Informação contida em extensa matéria jornalística feita pela Revista Época no ano de 2012. Disponível em http://revistaepoca.globo.com/tempo/noticia/2012/03/o-paciente-de-r-800-mil.html. Acesso em 11 de julho de 2015.

${ }^{5}$ Informação contida em extensa matéria jornalística feita pela Revista Época no ano de 2012. Disponível em http://revistaepoca.globo.com/tempo/noticia/2012/03/o-paciente-de-r-800-mil.html. Acesso em 11 de julho de 2015.
} 
tempo em que, desse modo, implicitamente revogou o art. $1^{\text {o }}$ da Lei Federal n. ${ }^{\circ}$ 9.494/97 (DIDIER JUNIOR; BRAGA; OLIVEIRA, 2015).

Hoje, portanto, é pertinente afirmarmos que, praticamente tal como acontecia antes da entrada em vigor do NCPC, é cabível a antecipação de tutela satisfativa ou cautelar em desfavor do poder público (ressalvadas as questões referentes à obrigação de pagar quantia e dos precatórios, que não são objeto deste trabalho).

A respeito da tutela provisória nas obrigações de fazer, não fazer e dar coisa distinta de dinheiro em face do poder público, que aqui nos interessam, algumas situações merecem ser destacadas. Nesse caso, não há possibilidade de antecipação de tutela em ação possessória contra o poder público sem sua oitiva prévia; o art. $1^{\circ}$ da Lei $n .^{\circ} 2.770 / 56$ veda a concessão de tutela provisória, em qualquer situação, nas ações que se referem à liberação de bens, mercadorias ou coisas de procedência estrangeira; e o art. $1^{\circ}, \S 5^{\circ}$ da Lei 8.437/92, o art. $7^{\circ}$, § $2^{\circ}$ da Lei 12.016/09 e o art. 1059 do NCPC, todos no mesmo sentido da súmula 212 do Superior Tribunal de Justiça, vedam a tutela provisória nas ações que tenham por finalidade a certificação de compensação tributária e previdenciária (DIDIER JUNIOR; BRAGA; OLIVEIRA, 2015).

Ademais, a tutela provisória contra o poder público continua proibida quando tiver a finalidade de reclassificar ou equiparar servidores públicos e conceder aumento ou a extensão de vantagens ou pagamento de qualquer natureza; quando estiver sendo impugnado, em primeira instância, ato de autoridade sujeita, pela via do mandado de segurança, à competência originária do tribunal, e, por fim, quando a medida esgotar o objeto da ação, no todo ou em qualquer parte, o que devidamente interpretado significa dizer, na verdade, que, desde que exista irreversibilidade, não haverá tutela provisória (DIDIER JUNIOR; BRAGA; OLIVEIRA, 2015).

Na jurisprudência, todas essas limitações, que sempre tiveram como centro as pretensões pecuniárias dos servidores públicos (DIDIER JUNIOR; BRAGA; OLIVEIRA, 2015), têm sido mitigadas, especialmente nos casos que envolvem o direito à saúde (concessão de medicamentos, de tratamentos, dentre outros), apesar do que foi decidido pelo STF na ADI 223-6 DF, quando ficou reconhecida a constitucionalidade das limitações à concessão de provimentos liminares contra o poder público em geral previstas na Lei Federal n. ${ }^{\circ}$ 9.494/97.

E dada a constitucionalidade das indicadas limitações, neste ponto é preciso dizer que, no caso concreto aqui apreciado, a constitucionalidade do dispositivo de lei que veda a tutela provisória que esgote, no todo ou em parte, o objeto da ação deveria ter sido enfrentada e afastada, em razão do conflito de valores existente (DIDIER JUNIOR; BRAGA; OLIVEIRA, 2015).

No caso de decisão interlocutória em apreço, portanto, como se trata tecnicamente de ação individual que tramitou pelo procedimento ordinário, com a finalidade de compelir a União a dar medicamentos ao paciente autor, dentre os quais o Soliris, é possível, em tese, a concessão da tutela de urgência por meio da antecipação da tutela satisfativa (desde que para tanto fosse, no caso concreto, afastada pelo juiz a constitucionalidade do art. $1^{\circ}$, $\S 3^{\circ}$, da Lei n. ${ }^{\circ} 8.437 / 1992$, aplicável à antecipação de tutela satisfativa).

Pois bem. Sucede que, na decisão analisada, o magistrado, para conceder a antecipação de tutela satisfativa, ao apreciar os pressupostos exigidos para tanto, também deixou de considerar corretamente os pressupostos para a antecipação de tutela das obrigações de fazer, não fazer ou de dar coisa distinta de dinheiro, os quais, aliás, no momento em que foi dada a decisão, como ainda estava em vigor o Código de Processo Civil de 1973, eram diferentes dos pressupostos previstos no art. 273, $\S 3^{\circ}$, do velho Código de Processo Civil.

\footnotetext{
${ }^{6}$ No art. $1^{\circ}$ da Lei Federal n. ${ }^{\circ}$ 9.494/97 estava disposto que "Aplica-se à tutela antecipada prevista nos arts. 273 e 461 do Código de Processo Civil o disposto nos arts. $5^{\circ}$ e seu parágrafo único e $7^{\circ}$ da Lei $n^{\circ} 4.348$, de 26 de junho de 1964 , no art. $1^{\circ}$ e seu $\S 4^{\circ}$ da Lei $n^{\circ} 5.021$, de 9 de junho de 1966 , e nos arts. $1^{\circ}, 3^{\circ}$ e $4^{\circ}$ da Lei $n^{\circ} 8.437$, de 30 de junho de 1992".
} 
Ao fazê-lo, na verdade, o magistrado valeu-se da simples transcrição de um julgado anterior (que nem antes nem hoje à luz do NCPC teria força vinculante em sentido estrito), sem, contudo, indicar sua ratio decidendi. Disse, reportando-se aos fundamentos constantes na decisão dada em processo que tramitou no Tribunal de Justiça de Rondônia, que versava sobre pedido do medicamento Soliris, e que chegou ao Superior Tribunal de Justiça e ao Supremo Tribunal Federal, que se faziam presentes a plausibilidade do direito invocado e a presença de risco de dano irreparável ou de difícil reparação no caso de indeferimento da antecipação de tutela e, além disso, que os casos eram iguais.

Contudo, devemos lembrar que a plausibilidade do direito invocado e a presença de risco de dano irreparável ou de difícil reparação não se confundiam com o relevante fundamento da demanda e o justificado receio de ineficácia do provimento final ${ }^{7}$, o que não foi observado nem na decisão em apreço nem no julgado nela invocado.

A esta altura é importante dizermos que, em que pese tenha sido o NCPC o responsável por prever novas hipóteses de pronunciamentos que devem ter caráter vinculante em sentido estrito, em maior ou menor proporção, e por especificar expressamente hipóteses em que uma decisão judicial não se encontra fundamentada, o dever de fundamentar (assim como a ideia de precedentes ligados aos pronunciamentos do STF em controle de constitucionalidade) já estava previsto na Constituição de 1988 , de tal sorte que a simples menção a um julgado anterior ${ }^{8}$ (com ou sem caráter vinculante forte) não seria, nem antes nem hoje, suficiente para que uma decisão fosse considerada fundamentada.

Por óbvio, a decisão interlocutória sob análise carece da necessária fundamentação, em que pese no momento em que foi proferida ainda estivesse em vigor o velho CPC. A ratio decidendi do julgado utilizado sequer foi identificada pelo juiz, sendo que, além do mais, não foram apreciados os pressupostos no caso concreto para a concessão de antecipação de tutela previstos à época no art. 461, § 3º do Código de Processo Civil de 1973.

Contudo, não poderemos aqui, onde pretendemos realizar a análise de uma decisão e não, um Estudo de Caso, adentrar na apreciação sobre o possível enfrentamento pela decisão em tela de todos os argumentos deduzidos no processo capazes de, em tese, informar a conclusão adotada pelo julgador, pois não é nosso propósito analisar o caso própria e intensivamente, o que nos permitiria apreciar a resposta da União, por exemplo. O Estudo de Caso, inclusive, segundo Freitas Filho e Lima (2010), é o estudo intensivo de uma decisão, de um grupo de decisões ou de uma questão-problema jurídica determinada, por meio da exploração da maior quantidade de variáveis nela envolvidas, numa perspectiva de múltiplas variáveis.

É indispensável lembrarmos que o art. 461, § $3^{\circ}$, e o art. 461-A, ambos do Código de Processo Civil de 1973, sobre a antecipação de tutela relacionada às obrigações de fazer, não fazer ou de dar coisa distinta de dinheiro, prescreviam que eram pressupostos para a sua concessão o relevante fundamento da demanda e o justificado receio de ineficácia do provimento final. Nesse caso é evidente que para a concessão de antecipação de tutela nas obrigações de fazer, não fazer ou de dar coisa distinta de dinheiro eram exigidos menos pressupostos do que para a antecipação de tutela nas obrigações pecuniárias, nas ações constitutivas e nas ações meramente declaratórias do art. 273, $\S 3^{\circ}$, do Código de Processo Civil revogado.

\footnotetext{
${ }^{7}$ Cumpre dizer que o novo Código de Processo Civil rompe com a distinção feita pelo Código de Processo Civil de 1973 entre os pressupostos da antecipação de tutela satisfativa e da tutela cautelar, dispondo que a tutela de urgência será concedida quando houver elementos que evidenciem a probabilidade do direito e o perigo de dano ou o risco ao resultado útil do processo.

${ }^{8}$ Sobre os precedentes, tem-se que o termo, no ordenamento jurídico brasileiro, possui duas acepções, uma tradicional ligada à ideia de um pronunciamento judicial proferido anteriormente e que, no futuro, será relevante para o julgamento de novos casos análogos ou idênticos, e, mais modernamente, entendido como pronunciamentos judiciais que já surgem com o propósito de funcionarem como parâmetro, para vincular decisões judiciais, atos administrativos ou até mesmo atos praticados no âmbito privado, de modo forte, médio ou fraco, desde que se refiram a casos que tenham a mesma questão jurídica (TALAMINI, 2016).
}

Revista de Direito Brasileira | São Paulo, SP | v. 20 | n. 8 | p. 104-127 |Mai./Ago. 2018 
Tendo em vista o Código de Processo Civil de 1973 em vigor ao tempo em que foi proferida a interlocutória sob análise, não é desnecessário lembrarmos, também, que o art. 461, § $3^{\circ}$, daquele $\mathrm{CPC}$ era caracterizado por sua textura normativa aberta, de forma que os pressupostos para a concessão da antecipação de tutela nas obrigações de fazer, não fazer e de dar coisa distinta de dinheiro, diferentemente do que ocorria com o art. 273, eram apenas o relevante fundamento da demanda e o justificado receio de ineficácia do provimento final. De qualquer modo, tais pressupostos deveriam ser demonstrados de forma justificada pelo magistrado no caso concreto.

Já quanto ao art. 273 do Código de Processo Civil, havia pressupostos obrigatórios e outros facultativos da antecipação de tutela nas obrigações de pagar quantia e nas ações constitutivas e meramente declaratórias. Os obrigatórios deviam ser observados sempre e, quanto aos facultativos bastava que um desses fosse observado para se conceder a antecipação de tutela. Eram pressupostos obrigatórios a prova inequívoca (pressuposto objetivo), a verossimilhança e a reversibilidade dos efeitos da decisão. A respeito dos pressupostos facultativos tínhamos que bastava a verificação de um deles, para que fosse cabível a antecipação de tutela, eram eles: o perigo (273, inciso I, CPC), o fundado receio de dano irreparável ou de difícil reparação, de forma que a tutela antecipada do inciso I fundava-se em evidência (prova inequívoca, verossimilhança e reversibilidade) e em perigo; ou o abuso do direito de defesa (art. 273, inciso II, CPC), que era o manifesto propósito protelatório.

Portanto, é bastante evidente que, mesmo ainda sem adentrarmos no mérito da decisão que concedeu provisoriamente o medicamento Soliris ao autor da demanda cível em antecipação de tutela, andou mal o magistrado ao fazer uso de julgado que, por si só, já apreciava equivocadamente os pressupostos para a concessão de antecipação de tutela, tal como também ocorreu com a decisão aqui analisada, sem, ademais, justificar devidamente a pertinência do caso em face da ratio decidendi da decisão anterior, pois, mesmo não estando em vigor o NCPC, o dever de fundamentar a decisão previsto na Constituição da República em grande parte já abrangia tudo que em seguida foi minuciosa e expressamente previsto no art. 498 , $\S 1^{\circ}$, do Código de Processo Civil de 2015.

A decisão aqui apreciada deveria levar em conta os pressupostos para a concessão da antecipação de tutela referentes ao fundamento da demanda e ao justificado receio de ineficácia do provimento final, pressupostos esses que, em face da textura bastante aberta, ao menos em tese não restringiam a concessão de antecipação de tutela nos casos que envolviam obrigações de dar coisa distinta de dinheiro, de fazer e de não fazer, mas exigiam consistente justificação.

No caso da decisão interlocutória analisada, devemos reforçar, o juiz utilizou-se de julgado que, tanto quanto ele o fez, equivocadamente analisou os pressupostos da antecipação de tutela, quando apreciou os pressupostos previstos no art. 273 do Código de Processo Civil de 1973.

Portanto, a análise da fundamentação contida na decisão interlocutória para a concessão da antecipação de tutela deixa evidente a existência concomitante de error in procedendo derivado da falta de fundamentação, que se restringiu à simples menção a precedente, e de error in judicando advindo da apreciação de pressupostos para a antecipação de tutela não cabíveis para as obrigações de dar coisa distinta de dinheiro, de fazer ou de não fazer.

\section{A EXISTÊNCIA DE POLÍTICAS PÚBLICAS DE MEDICAMENTO E DE ASSISTÊNCIA FARMACÊUTICA E O TRATAMENTO LEGAL DADO AO FORNECIMENTO DE MEDICAMENTOS EXCEPCIONAIS NO BRASIL PELO SUS}

O Brasil, por meio do Decreto n. ${ }^{\circ}$ 53.612, de 26 de fevereiro de 1964, estabeleceu a Relação Básica e Prioritária de Produtos Biológicos e Matérias de Uso Farmacêutico Humano e 
Veterinário, antecipando-se, portanto, à Organização Mundial de Saúde, que somente no ano de 1977 elaborou a sua primeira lista-modelo de medicamentos essenciais (BERMUDEZ, 1995).

Por aqui, antecedendo de mesmo modo a Constituição de 1988, foi a Lei Federal n. ${ }^{\circ}$ 6.360/76 que dispôs sobre a vigilância sanitária a que estão sujeitos os medicamentos em geral. No art. 12 dessa lei consta a expressa vedação a que qualquer produto tratado no referido diploma normativo, medicamentos, drogas, insumos farmacêuticos e correlatos, cosméticos, saneantes e outros produtos, inclusive os produtos importados, seja industrializado, exposto à venda ou entregue ao consumo antes de registrado no Ministério da Saúde (hoje a Anvisa é a agência reguladora que cuida dessa matéria).

Essa é, portanto, uma importante barreira legal à questão do fornecimento de medicamentos no Brasil, inclusive, pela via judicial, pois podemos afirmar que temos norma jurídica clara sobre o regime administrativo sanitário de importação, industrialização, venda ou simples entrega ao consumo dos produtos de que trata a Lei Federal n. ${ }^{\circ}$ 6.360/76. Essa norma, aliás, objetiva assegurar a saúde e a vida daqueles que podem vir a necessitar dos produtos tratados pela indicada lei.

Em 1998, no Brasil, foi aprovada a Política Nacional de Medicamentos, por meio da Portaria n. ${ }^{\circ}$ 3.916, de 30 de outubro de 1998, a qual estabeleceu que medicamentos precisam ser seguros, eficazes e de qualidade, oportunidade em que passou a promover o uso racional e o acesso da população aos medicamentos considerados essenciais. Dentre as diretrizes dessa política, as prioritárias dizem respeito à revisão permanente da RENAME (Relação Nacional de Medicamentos Essenciais), a reorientação da Assistência Farmacêutica, a organização das atividades ligadas à Vigilância Sanitária dos medicamentos e a promoção do uso racional desses.

À frente, no ano de 2004, por meio da Resolução n. ${ }^{\circ} 338$ do Conselho Nacional de Saúde - CNS foi aprovada a Política Nacional de Assistência Farmacêutica, que redefiniu essa assistência enquanto uma política que deve nortear a elaboração de políticas setoriais, a exemplo das políticas de medicamentos, ciência e tecnologia, desenvolvimento industrial, formação de recursos humanos, assegurando a intersetorialidade e envolvendo os setores público e privado de atenção à saúde.

Nesse contexto, tem-se que o fornecimento pelo Sistema Único de Saúde de medicamentos essenciais está inserido em políticas públicas de medicamentos e de assistência farmacêutica, que possuem âmbito nacional, existindo, ainda, programa destinado ao fornecimento de medicamentos em caráter excepcional.

Vale dizer que os medicamentos essenciais são aqueles que se prestam à satisfação das necessidades de atenção à saúde da maioria da população, devendo ser escolhidos conforme a sua relevância para a saúde pública e, também, estar disponíveis em todos os momentos e nas quantidades adequadas, nas formas farmacêuticas pedidas e a preços que indivíduos e a comunidade sejam capazes de pagar (MOSEGUI et al, 1999). Já os medicamentos excepcionais são os que se destinam ao tratamento de patologias específicas, que atingem número limitado de pacientes, os quais, na maioria das vezes, necessitam dos medicamentos por períodos prolongados.

Nesse ponto é importante lembrarmos que a assistência farmacêutica integra a atenção à saúde, daí porque merece tratamento pelo Estado brasileiro, tendo em conta que a Constituição da República diz, no art. 196, que a saúde é direito de todos e dever do Estado, que deve ser garantido mediante políticas sociais e econômicas que tenham como objetivo a redução do risco de doença e de outros agravos e o acesso universal e igualitário às ações e serviços para sua promoção, proteção e recuperação. Devemos acrescer a isso o fato de que a Constituição de 1988, no art. 197, ainda tratou de expressamente prever que ações e serviços de saúde são de relevância pública.

Essa relevância pública tem dupla consequência. Num primeiro momento, ela significa que o direito à saúde deve ser garantido por meio da atuação do Estado, ainda quando os serviços 
e ações de saúde - os únicos que podem não ser exercidos exclusivamente pelo Estado - forem prestados por particulares. Nesse caso, tem-se que os prestadores privados desses serviços têm liberdade limitada pelo Estado, que é o único que deve dar a direção da prestação de serviços e ações de saúde, estabelecendo diretrizes e parâmetros (FERRAZ; BENJAMIN, 1994).

Num segundo momento, a mencionada relevância pública deve ser interpretada a partir da combinação do art. $197^{9}$ com o art. 129, inciso II, ambos da Constituição ${ }^{10}$, de forma que dentre as funções institucionais do Ministério Público encontra-se a função de zelar pelo efetivo respeito dos Poderes Públicos às ações e serviços de saúde, promovendo as medidas necessárias à sua garantia (FRISCHEISEN, 2000). Nesse caso, a atribuição do Ministério Público é dirigida para os atos praticados pelos poderes púbicos e também pelos particulares, quando ligados aos serviços ou ações de relevância pública.

Portanto, a assistência farmacêutica efetivamente integra a atenção à saúde, sendo que o Estado brasileiro trata não apenas do fornecimento de medicamentos essenciais, devidamente previstos nas listas formuladas pelos entes públicos, como também dispensa tratamento aos medicamentos excepcionais que cuidam de doenças igualmente excepcionais.

Foi, aliás, a Lei Orgânica da Saúde, Lei Federal n..$^{\circ}$ 8.080/90, a qual regulamenta o Sistema Único de Saúde, que fixou a organização básica das ações e dos serviços de saúde. Em seu art. $6^{\circ}$, a indicada lei tratou de assegurar a assistência terapêutica integral, incluindo a assistência farmacêutica.

A respeito do princípio do atendimento integral à saúde esculpido originariamente no art. 198, inciso II, da Constituição da República, é importante dizer que esse funciona como verdadeira diretriz para o Sistema Único de Saúde (SUS), o que significa que todas as ações e os serviços de saúde compõem uma realidade una, que não pode ser separada, devendo formar um todo harmonioso (SCHWARTZ, 2004).

Essa assistência integral quer dizer que:

o cidadão tem o direito de ser atendido e assistido sempre que necessitar, em qualquer situação de risco ou agravo (doença), utilizando ou não insumos, medicamentos, equipamentos, entre outros. Ou seja, o que define o atendimento deve ser a necessidade das pessoas. (SCHWARTZ, 2004)

E a assistência farmacêutica, que compõe essa integralidade, pode ser definida como sendo o conjunto de medidas que pretende possibilitar o fornecimento de medicamentos, incluindo o acesso propriamente a esses e seu uso racional. A integralidade abrange a pesquisa, o desenvolvimento, a produção, a seleção, a programação, a aquisição, a distribuição, a dispensação, devendo ser garantidos a qualidade, o acompanhamento e a avaliação do uso, tudo com a finalidade de propiciar melhoria da qualidade de vida. Ademais, dita integralidade perpassa a ideia de acesso rápido, eficaz e adequado, consideradas as necessidades de quem faz uso dos medicamentos.

E foi em decorrência da Constituição de 1988 e da Lei Orgânica do SUS, as quais consagraram os princípios do Movimento de Reforma Sanitária, que, no ano de 1998, como dito antes, foi aprovada, pela Comissão Intergestores e pelo Conselho Nacional de Saúde, a Política Nacional de Medicamentos, por meio da Portaria n. ${ }^{\circ}$ 3.916, de 30 de outubro de 1998, ao passo

\footnotetext{
${ }^{9}$ O art. 197 da Constituição da República dispõe que: “Art. 197. São de relevância pública as ações e serviços de saúde, cabendo ao Poder Público dispor, nos termos da lei, sobre sua regulamentação, fiscalização e controle, devendo sua execução ser feita diretamente ou através de terceiros e, também, por pessoa física ou jurídica de direito privado."

${ }^{10}$ Diz o art. 129, inciso II, da Constituição da República, que: “Art. 129. São funções institucionais do Ministério Público: (...) II - zelar pelo efetivo respeito dos Poderes Públicos e dos serviços de relevância pública aos direitos assegurados nesta Constituição, promovendo as medidas necessárias a sua garantia;”.
} 
que na formulação da Política Nacional de Medicamentos foram levadas em consideração as diretrizes da Organização Mundial da Saúde, que objetivam garantir a segurança, a eficácia e a qualidade desses produtos, além da promoção do uso racional e o acesso da população aos medicamentos considerados essenciais (OLIVEIRA; LABRA; BERMUDEZ, 2006).

A aprovação da Política Nacional de Assistência Farmacêutica, por meio da Resolução n. ${ }^{\circ}$ 338/2004, em 2004, significou, de fato, o estabelecimento de uma política nacional mais ampla e preocupada com os recursos destinados ao custeio da assistência farmacêutica, ocasião em que se pretendeu tratar de:

Um conjunto de ações voltadas à promoção, proteção e recuperação da saúde, tanto individual como coletiva, tendo o medicamento como insumo essencial e visando o acesso e seu uso racional. Este conjunto envolve a pesquisa, o desenvolvimento e a produção de medicamentos e insumos, bem como a sua seleção, programação, aquisição, distribuição, dispensação, garantia da qualidade dos produtos e serviços, acompanhamento e avaliação de sua utilização, na perspectiva da obtenção de resultados concretos e da melhoria da qualidade de vida da população. (BRASIL, 2014, on line)

Vemos, nesse sentido, que existem no Brasil Políticas Públicas de Assistência Farmacêutica e de Medicamentos, sendo que o Estado brasileiro tratou de cuidar dos medicamentos essenciais, que compõem uma farmácia básica, em regra de baixo custo unitário, e que são destinados ao tratamento da maior parte das enfermidades que atingem a população brasileira, sem deixar de lado os medicamentos excepcionais, caracterizados por serem utilizados no tratamento de doenças crônicas, de caráter individual e que atingem um número menor de pessoas, mas que exigem tratamento a longo prazo ou permanente, e são de alto custo. Tais medicamentos excepcionais também estão inseridos na Política Nacional de Medicamentos.

A respeito dos medicamentos excepcionais, vale apontarmos que, em 1982, portanto, antes do advento da Constituição da República, nasceu, por meio de portarias, o Programa de Medicamentos de Dispensação em Caráter Excepcional. Todavia, como até o ano de 1999 a inclusão ou exclusão de medicamentos no programa era realizada por simples pareceres técnicos, a partir daquele ano a Portaria GM/MS n. ${ }^{\circ} 1.310$ criou a Comissão de Assessoria Farmacêutica vinculada à Secretaria de Assistência à Saúde (SAS), que passou a ser constituída com representantes de diversos setores do Estado e até do Conselho Nacional de Secretários de Saúde e do Conselho Nacional de Secretarias Municipais de Saúde. A referida Comissão deve estabelecer critérios técnicos para seleção, inclusão, exclusão e substituição de medicamentos excepcionais da tabela SIA/SUS (CARIAS et ali, 2011).

A partir de 2001, com o objetivo de fixar critérios de diagnóstico de cada doença, além de critérios para a inclusão e exclusão de pacientes ao tratamento, estabelecendo a dosagem correta, além de formas de controle, acompanhamento e avaliação, o Ministério da Saúde passou a divulgar protocolos clínicos e diretrizes terapêuticas (CARIAS et ali, 2011).

No ano 2006, a Portaria GM/MS n. 2.577 regulamentou o Programa de Medicamentos de Dispensação em Caráter Excepcional, oportunidade em que definiu a lista de medicamentos, as doenças para as quais sua prescrição é autorizada, conforme a CID-10, e as normas de acesso ao Programa, dentre outras providências (CARIAS et ali, 2011).

Adiante, a Portaria GM/MS n. ${ }^{\circ} 2.981$ de 2009 modificou a definição e a denominação do programa, que passou a ser tratado como Componente Especializado da Assistência Farmacêutica. A referida portaria definiu o programa como estratégia de acesso a medicamentos no âmbito do Sistema Único de Saúde, caracterizado pela busca da integralidade do tratamento medicamentoso na assistência ambulatorial, cujas linhas de cuidado foram definidas em protocolos clínicos e diretrizes terapêuticas publicados pelo Ministério da Saúde (CARIAS et ali, 2011). 
Desse modo, a inclusão de novos medicamentos no Programa hoje tratado como Componente Especializado da Assistência Farmacêutica necessita de embasamento nas ciências médicas, de estudos que sejam capazes de demonstrar a eficácia, a segurança e a vantagem tendo em conta a opção terapêutica que deve ser disponibilizada, o que implica apreciar o custo em relação à eficácia ou à segurança e questões mercadológicas (CARIAS et ali, 2011).

Portanto, em que pese seja imprescindível que a sociedade brasileira discuta, por meio do debate democrático, a abrangência e os possíveis limites da integralidade, considerando, inclusive, que o direito à saúde é social tratado na Constituição de 1988 como coletivo, embora obviamente seja a saúde também direito individual $^{11}$ - sabendo-se sempre que, de qualquer modo, inexistem direitos fundamentais absolutos -, é fato que existe no Brasil um programa dedicado a tratar da assistência farmacêutica no tratamento de doenças crônicas e/ou raras, em nível ambulatorial, no Sistema Único de Saúde. E, nesse programa, para que os medicamentos sejam dispensados em farmácias especializadas, existem normas jurídicas dispondo sobre o procedimento prévio a ser seguido para a inclusão e exclusão dos medicamentos especializados em lista, estando tudo isso estruturado por força de atos normativos do Ministério da Saúde.

Assim, tendo em conta as características de algumas doenças e o custo dos medicamentos especializados, existem no Brasil critérios específicos definidos nos protocolos clínicos e diretrizes terapêuticas do Ministério da Saúde, que assumem o status de normas jurídicas, as quais, se não questionadas judicialmente e assim afastadas por inconstitucionalidade, devem ser seguidas, gozando, aliás, de presunção de legalidade, enquanto atos administrativos que são.

Não bastasse tudo isso, no ano de 2011 foi aprovada no Congresso Nacional e entrou em vigor a Lei Federal n. ${ }^{\circ}$ 12.401, que alterou a Lei Orgânica da Saúde, para dispor sobre a assistência terapêutica e a incorporação de tecnologia em saúde no âmbito do Sistema Único de Saúde - SUS.

Segundo a mencionada Lei n. ${ }^{\circ} 12.401 / 2011$, a assistência terapêutica integral consiste na dispensação de medicamentos e produtos de interesse para a saúde, cuja prescrição deve estar em conformidade com as diretrizes terapêuticas definidas em protocolo clínico para a doença ou o agravo à saúde a ser tratado ou, na falta do protocolo, em conformidade com o que foi previsto no art. 19-P. Além disso, diz essa lei que a assistência terapêutica integral consiste na oferta de procedimentos terapêuticos, em regime domiciliar, ambulatorial e hospitalar, constantes de tabelas elaboradas pelo gestor federal do Sistema Único de Saúde - SUS, realizados no território nacional por serviço próprio, conveniado ou contratado. Ficou, assim, reforçada a necessidade de previsão em tabelas oficiais.

De acordo com a indicada lei, para a realização da assistência terapêutica integral devese respeitar os protocolos clínicos e as diretrizes terapêuticas, que fixarão os medicamentos ou produtos necessários nas diferentes fases evolutivas da doença ou do agravo à saúde de que tratam, bem como aqueles indicados em casos de perda de eficácia e de surgimento de intolerância ou reação adversa relevante, provocadas pelo medicamento, produto ou procedimento de primeira escolha, devendo os medicamentos ou produtos ser avaliados quanto à sua eficácia, segurança, efetividade e custo-efetividade para as diferentes fases evolutivas da doença ou do agravo à saúde de que trata o protocolo.

Essa nova lei, que alterou a Lei Orgânica da Saúde, prevê, também, como deverá o SUS atuar, quando da ausência de protocolo clínico ou de diretriz terapêutica, na dispensação de medicamentos.

\footnotetext{
${ }^{11}$ Para Dallari (1988), o direito à saúde enquanto direito individual enfatiza a liberdade em sentido amplo. Assim, as pessoas podem escolher a relação que terão com o meio ambiente, onde viverão, o tipo de vida que terão, as condições de trabalho, e, se doentes, os recursos médicos e sanitários que buscarão.
} 
E, a respeito da incorporação, exclusão ou alteração pelo SUS de novos medicamentos, produtos ou tratamentos e até da constituição ou alteração de protocolo clínico ou diretriz terapêutica, a nova lei trouxe regras claras, nos arts. 19-Q e 19-R.:

Art. 19-Q. A incorporação, a exclusão ou a alteração pelo SUS de novos medicamentos, produtos e procedimentos, bem como a constituição ou a alteração de protocolo clínico ou de diretriz terapêutica, são atribuições do Ministério da Saúde, assessorado pela Comissão Nacional de Incorporação de Tecnologias no SUS.

$\S 1^{\circ}$ A Comissão Nacional de Incorporação de Tecnologias no SUS, cuja composição e regimento são definidos em regulamento, contará com a participação de 1 (um) representante indicado pelo Conselho Nacional de Saúde e de 1 (um) representante, especialista na área, indicado pelo Conselho Federal de Medicina.

$\S 2^{\circ} \mathrm{O}$ relatório da Comissão Nacional de Incorporação de Tecnologias no SUS levará em consideração, necessariamente:

I - as evidências científicas sobre a eficácia, a acurácia, a efetividade e a segurança do medicamento, produto ou procedimento objeto do processo, acatadas pelo órgão competente para o registro ou a autorização de uso;

II - a avaliação econômica comparativa dos benefícios e dos custos em relação às tecnologias já incorporadas, inclusive no que se refere aos atendimentos domiciliar, ambulatorial ou hospitalar, quando cabível.

Art. 19-R. A incorporação, a exclusão e a alteração a que se refere o art. 19-Q serão efetuadas mediante a instauração de processo administrativo, a ser concluído em prazo não superior a 180 (cento e oitenta) dias, contado da data em que foi protocolado o pedido, admitida a sua prorrogação por 90 (noventa) dias corridos, quando as circunstâncias exigirem.

$\S 1^{\circ} \mathrm{O}$ processo de que trata o caput deste artigo observará, no que couber, o disposto na Lei no 9.784, de 29 de janeiro de 1999, e as seguintes determinações especiais:

I - apresentação pelo interessado dos documentos e, se cabível, das amostras de produtos, na forma do regulamento, com informações necessárias para o atendimento do disposto no $\S 20$ do art. 19-Q;

II - (VETADO);

III - realização de consulta pública que inclua a divulgação do parecer emitido pela Comissão Nacional de Incorporação de Tecnologias no SUS;

IV - realização de audiência pública, antes da tomada de decisão, se a relevância da matéria justificar o evento.

Portanto, aquilo que antes estava previsto em atos administrativos sobre a incorporação, exclusão ou alteração pelo SUS de novos medicamentos, produtos ou tratamentos, agora está também prescrito em lei.

Mais do que isso, o art. 19-T é importantíssimo para a análise da decisão interlocutória ora em comento, quando estabelece que:

Art. 19-T. São vedados, em todas as esferas de gestão do SUS:

I - o pagamento, o ressarcimento ou o reembolso de medicamento, produto e procedimento clínico ou cirúrgico experimental, ou de uso não autorizado pela Agência Nacional de Vigilância Sanitária - ANVISA;

II - a dispensação, o pagamento, o ressarcimento ou o reembolso de medicamento e produto, nacional ou importado, sem registro na Anvisa." 
A Lei Orgânica da Saúde, alterada pela Lei n. ${ }^{\circ}$ 12.401/2011, todavia, não foi sequer mencionada na justificação da decisão analisada, não tendo também sido afastada sua constitucionalidade, o que implica dizermos que ela vale, mas não foi aplicada.

Temos, assim, que a Lei Orgânica da Saúde, quando trata da assistência farmacêutica, e o fato de que o Estado brasileiro possui Política Nacional de Medicamento e um programa que trata da dispensação de medicamentos em caráter excepcional, o Componente Especializado de Assistência Farmacêutica - CEAF, não foram considerados no momento da decisão interlocutória analisada presentemente.

Quanto à Lei Federal n. ${ }^{\circ}$ 6.360/76, que trata da industrialização, venda ou simples entrega ao consumo dos produtos sobre os quais deve recair a atividade de vigilância sanitária, no julgado utilizado para fundamentar a concessão do Soliris consta que, segundo o STF, a falta de registro na Anvisa poderia ser óbice ao pedido formulado contra o SUS, o que diz não ocorrer, todavia, porque o medicamento é o único que existe para a enfermidade do autor da demanda. A Corte Suprema, portanto, nem se deu ao trabalho de afastar a constitucionalidade do dispositivo previsto na Lei Federal n. ${ }^{\circ}$ 6.360/76. Apenas não a considerou em face do direito fundamental à saúde ${ }^{12}$.

O fundamento para a concessão da antecipação de tutela requerida pelo autor foi, exclusivamente, a aplicação direta do art. 196 da Constituição da República, que trata do direito à saúde.

A esta altura é importante lembramos que, além do art. 196 da Constituição da República, a integralidade prevista no art. 198, inciso II, da Constituição, tem sido o fundamento direto e geralmente único para as decisões judiciais sobre medicamentos e tratamentos, mesmo sem que sejam enfrentados, em primeiro lugar, o fato de que o direito à saúde é direito social tratado enquanto coletivo na Constituição, e, em segundo lugar, a profundidade dessa integralidade.

O não enfrentamento das normas jurídicas que tratam de políticas públicas de saúde e até mesmo da temática da discricionariedade do ato administrativo, da conveniência e da oportunidade desses (o que por si só daria um tratado de Direito Administrativo), obviamente, faz com que o Sistema Único de Saúde, gerido antes de tudo de modo ineficiente pelo Executivo, seja também de péssimo modo "administrado" pelo Poder Judiciário, que decide independentemente da superação da lei em vigor e do enfrentamento das questões de Direito Administrativo e de Direito Sanitário, desprezando também questões técnicas ligadas às Ciências Médicas.

Decisões judiciais, assim, são nefastas para o Sistema Único de Saúde, especialmente porque, ao dizerem respeito à prestação de determinados serviços e ao fornecimento de certos medicamentos aos que pedem a tutela jurisdicional via de regra por meio de demandas judiciais individuais, as decisões proferidas nessas demandas, pela própria natureza individual, impedem o Judiciário de pelo menos decidir tendo em vista os interesses públicos e coletivos. Dessa sorte, e estamos falando literalmente de sorte, diante de um SUS que funciona muito mal em geral, quem tem a chance de ir ao Judiciário, pode obter até pela aplicação direta de normas jurídicas previstas na Constituição, por exemplo, o medicamento mais caro do mundo.

A esta altura devemos lembrar que, mesmo antes do advento da Lei 12.401/2011, quanto à assistência farmacêutica já existiam regras para a inclusão e a exclusão dos medicamentos no SUS, sendo que havia previsão de procedimentos para o acesso aos medicamentos do CEAF, que

\footnotetext{
${ }^{12} \mathrm{~A}$ enxurrada de ações individuais e também a propositura de inúmeras ações coletivas versando sobre medicamentos e tratamentos de saúde hoje no Brasil ensejaram o reconhecimento de repercussão geral nos Recursos Extraordinários 566471 e 657718, ambos ainda sob julgamento do STF. Esses recursos, sem conclusão de julgamento, tratam do fornecimento de remédios de alto custo não disponíveis na lista do Sistema Único de Saúde (SUS) e de medicamentos não registrados na Agência Nacional de Vigilância Sanitária (Anvisa).
}

Revista de Direito Brasileira | São Paulo, SP | v. 20 | n. 8 | p. 104-127 |Mai./Ago. 2018 
são definidos pelo Ministério da Saúde, e constavam da Portaria GM/MS nº 1.554 de 30 de julho de 2013, Anexos I, II, III, IV e V.

Aplicando diretamente norma constitucional referente ao direito fundamental à saúde, na decisão sob análise o magistrado simplesmente desconsidera - sem nada dizer a respeito - o fato de que existe no Brasil uma Política Nacional de Medicamentos e o Componente Especializado de Assistência Farmacêutica destinado ao tratamento de doenças raras e/ou crônicas. Não enfrenta o fato de que, para ter acesso gratuito aos medicamentos, o usuário do Sistema Único de Saúde deverá conferir se o medicamento solicitado e a patologia constam na relação atendida pelo Componente, requerendo, em seguida, a partir da apresentação do Laudo para Solicitação de Medicamentos devidamente preenchido pelo Médico e a Prescrição Médica, de unidades SUS ou particulares, desde que inscritos no CNES, o medicamento.

Não considera o magistrado, ademais, que, conforme o ordenamento jurídico brasileiro, após essa solicitação, o processo passará por uma avaliação técnica e, se estiver de acordo com os Protocolos Clínicos e Diretrizes Terapêuticas - PCDT específicos para as doenças autorizadas pelo Ministério da Saúde, o paciente será aprovado para a retirada dos medicamentos.

Assim, diante de um medicamento não incluído no Componente Especializado de Assistência Farmacêutica, seria menos problemático se, por meio de ação coletiva, fosse levada ao Judiciário, que hoje tem superado a ideia de que o mérito administrativo não poderia ser discutido judicialmente (questão que, por si só, já constitui um problema, inclusive, pela falta de sua superação expressa e fundamentada pelo juiz), a discussão sobre a inclusão do medicamento não constante em listas oficiais. Ainda assim, aqui poderiam ser discutidas a admissibilidade da intromissão do Judiciário no mérito dos atos administrativos e também seu papel diante de políticas públicas já existentes.

De qualquer modo, é imprescindível registrarmos também que a questão de mercado perpassa todos os debates sobre os medicamentos essenciais e, com mais força, as discussões sobre os medicamentos excepcionais, fato que o Judiciário e até mesmo os colegitimados para a ação civil pública, especialmente o principal deles, o Ministério Público, não podem desconsiderar. Nesse sentido, na decisão presentemente analisada é válido observarmos que o Soliris é produzido sem qualquer concorrência por um laboratório estrangeiro.

Enquanto isso, na decisão do Supremo Tribunal Federal citada como fundamento para a decisão sob apreço, temos o argumento segundo o qual o alto custo do medicamento não ocasiona grave lesão à economia e à saúde públicas, porque existe a Política Pública de Dispensação de Medicamentos excepcionais.

Todavia, é impossível não notarmos a existência de um sério descompasso argumentativo, para não dizermos de uma contradição em si, pois a decisão reconhece que existe no Brasil uma política pública que trata de medicamentos, mas não a enfrenta e ainda a desconsidera sem qualquer justificativa.

\section{O ATIVISMO JUDICIAL E A DECISÃO CONCESSIVA DO "REMÉDIO MAIS CARO DO MUNDO"}

Há algum tempo o ativismo judicial, termo surgido nos Estados Unidos fora do universo acadêmico e dos tribunais para (re)tratar a atuação da Suprema Corte Americana, passou a ser discutido no Brasil, não apenas quando se trata da jurisdição constitucional, como também quando analisamos decisões do Poder Judiciário em processos concretos.

Nos Estados Unidos da América, num contexto constitucional distinto do brasileiro, o termo ativismo judicial surgiu em 1947, num trabalho de natureza jornalística do historiador Arthur M. Schlesinger Junior, publicado na revista de atualidades Fortune, no qual o autor tentava desenhar o quadro ideológico dos juízes da suprema corte americana. 
Naquela oportunidade, juízes como Black e Douglas foram chamados de juízes ativistas, e descritos como sendo aqueles que acreditavam que a Constituição e as leis tinham textura aberta, circunstância que autorizava a interpretação dessas de acordo com a ideia de justiça social. Foram assim descritos como aqueles para os quais a política e o direito eram inseparáveis. Por outro lado, juízes como Frankfurter e Jackson, denominados de campeões da autocontenção, ao contrário dos anteriores, pareciam resistir à ideia de supremacia do Judiciário, em nome da deferência à vontade do Legislativo, de sorte a preservar a separação dos poderes e o processo democrático. Nessa concepção, os juízes deveriam apenas resguardar a lisura dos procedimentos (SCHLESINGER, 1947).

Ainda segundo Schlesinger, haveria um terceiro grupo intermediário, sendo que, todavia, interessava-lhe o fato de que o primeiro grupo acreditava que a Suprema Corte podia desempenhar um papel afirmativo na promoção do bem-estar social, enquanto o segundo defendia uma política de autocontenção judicial (SCHLESINGER, 1947).

Em que pese o conceito de ativismo tenha guardado, ao longo do tempo, uma indeterminação semântica, como nos explica Gonet (2011), é certo que o termo possui, originalmente, relação com o contexto constitucional americano, caracterizado por uma Constituição rígida e sintética, cujo texto foi alterado ao longo de mais de duzentos anos, conforme dito antes aqui, por apenas 27 (vinte e sete) emendas, no qual consta um modelo clássico de separação dos poderes.

Ademais, em que pese a Constituição americana tenha regras que a tornam de difícil modificação e a supremacia seja uma de suas inegáveis características, seu texto não traz previsão expressa de competência do Judiciário para realizar o controle de constitucionalidade das leis nem de um órgão que deva cumprir tal missão, o que não impediu o nascimento e o desenvolvimento da judicial review of legislation como decorrência do poder de interpretação das leis que possui cada juiz (SÁNCHEZ, 1988).

Segundo Gonet (2011), apesar do termo ativismo judicial, mesmo nos Estados Unidos da América, sempre ter padecido de indeterminação semântica, ele tem sido utilizado, tanto lá quanto cá, ora para criticar ora para aplaudir o exercício arrojado da jurisdição, um exercício fora do comum, sobretudo quando envolve escolhas morais e políticas.

Diferentemente do contexto estadunidense, no Brasil temos uma Constituição prolixa, uma divisão de poderes que se abre, primeiramente, para a judicialização de tudo quanto há, e, também, para o ativismo ou, melhor dizendo por aqui, para um protagonismo do Judiciário. Em nossa Constituição, além disso, temos um longo rol de direitos fundamentais, dentre os quais os direitos sociais, que demandam prestação por parte do Estado, um Supremo Tribunal Federal que é guardião da Constituição e ao qual compete realizar o controle concentrado de constitucionalidade das leis, sendo os tribunais estaduais igualmente autorizados a efetivar tal controle, ao que se soma a permissão constitucional do controle de constitucionalidade difuso, que pode ser realizado por qualquer juiz perante um caso concreto.

Ao mesmo tempo, no Brasil, a extensa previsão de direitos fundamentais não foi acompanhada da previsão de mecanismos ou diretrizes de efetivação desses direitos, ao que se soma o fato de que as normas jusfundamentais que sobre tais direitos versam levam a debates sobre os seus limites e restrições, de modo que também o Judiciário pode ser perfeitamente chamado a defini-los, por força da opção do legislador constituinte, desde que, obviamente, seja respeitado o núcleo essencial de cada direito fundamental, oportunidade em que acaba o juiz por tratar do conteúdo e do âmbito de direitos fundamentais.

Ocorre que, nos Estados Unidos, país da common law, em que a Constituição sintética diz muito menos do que a Constituição brasileira, a tomada de decisões políticas pela Suprema Corte evidentemente produz uma sensação maior de anomalia do que no Brasil, onde a Constituição analítica acaba por limitar de forma mais rigorosa as opções políticas que estão 
sujeitas ao jogo das forças partidárias ordinárias por meio da imposição de valores enumerados de modo mais detalhado à esfera pública (GONET, 2011).

Contudo, tanto num ambiente em que impera uma Constituição sintética, na qual pouco foi dito, quanto num ambiente em que a Constituição é prolixa, a depender de um conjunto de fatores que podem estar presentes no derradeiro, decisões ativistas poderão ocorrer. Além disso, havemos de considerar que o controle de constitucionalidade na América, país de common law, pode ser realizado por qualquer juiz no caso concreto, enquanto no Brasil, um país historicamente de civil law, embora tenhamos uma Constituição prolixa e leis praticamente sobre todos os assuntos possíveis, pode haver controle de constitucionalidade concentrado e também difuso.

Sobre o ativismo no Brasil, Gonet (2011) lembra-nos de que nosso modelo de separação dos poderes, que reservou ao Judiciário o papel de guardião e de patrocinador de princípios dedutíveis de normas de direito fundamental, não é surpreendente que decisões judiciais ativistas possam existir.

E, apesar da imprecisão semântica do termo ativismo judicial, é possível identificarmos alguns fatores que podem indicar uma propensão ao ativismo, em detrimento de uma postura de autocontenção, o que pode nos permitir analisar a decisão interlocutória aqui tratada.

$\mathrm{Na}$ decisão interlocutória examinada verificamos que o fundamento para a concessão do medicamento mais caro do mundo ao autor foi o art. 196 da Constituição da República. Houve, no caso, uma direta aplicação do dispositivo constitucional que trata do direito fundamental à saúde.

Mesmo existindo no Brasil uma Política Nacional de Medicamentos, uma Lei Federal n. ${ }^{\circ}$ 6.360/76, que versa sobre a vedação da importação, industrialização, venda ou entrega ao consumo de medicamentos no Brasil sem registro na Anvisa, a Lei Orgânica da Saúde, alterada que foi, em 2011, pela Lei n. ${ }^{\circ}$ 12.401/2011, além de normas que dispõem sobre a política pública de fornecimento pelo Sistema Único de Saúde de medicamentos de caráter excepcional, que estão materializadas no Componente Especializado de Assistência Farmacêutica, o qual diz respeito ao tratamento de doenças raras e/ou crônicas, a antecipação de tutela analisada foi fundamentada em simples menção a julgado do Supremo Tribunal Federal, que aplicou diretamente a norma constitucional do direito à saúde a outro caso em que o Soliris foi pleiteado e efetivamente concedido pelo Judiciário a um paciente do SUS.

É evidente a constatação de que decisões fundadas na aplicação direita de normas jusfundamentais tendem ao ativismo judicial, tendem a uma atuação desinibida do Poder Judiciário. Nesse sentido é importante apontarmos que vários direitos previstos na Constituição são previstos de modo vago, como ocorre, por exemplo, com o direito à saúde, o que pode favorecer o poder criativo do juiz.

Na decisão analisada é possível verificarmos uma não consideração silenciosa pelo trabalho do legislador, uma desconsideração da norma jurídica criada pelo Legislativo, que tratou de alterar a Lei Orgânica da Saúde, dispondo sobre a assistência farmacêutica de modo detalhado, sendo que, quanto à lei federal que versa sobre o registro sanitário de medicamentos no Brasil, mesmo sem ter sido afastada sua constitucionalidade, o julgado utilizado como fundamento na decisão interlocutória examinada restringiu-se a dizer que, como o Soliris é o único medicamento adequado à enfermidade do autor da demanda, aquela lei não deve impedir a concessão da droga. E a desconsideração segue, pois podemos constatar igual atitude em relação às normas jurídicas que tratam do orçamento da saúde ${ }^{13}$ e do orçamento público em geral e o pior e mais eloquente silêncio, aquele que se notabiliza pela total desconsideração da política pública pré-existente que trata do fornecimento de medicamentos para doenças crônicas e/ou raras.

\footnotetext{
${ }^{13}$ Em 2005, o Ministério da Saúde foi citado em 387 ações. Gastou R \$ 2,4 milhões para atender essas três centenas de pacientes. Em 2011, foram 7.200 ações.A conta disparou para R \$ 243 milhões. Fonte: Revista Época, 16/03/2012. Disponível em<http://revistaepoca.globo.com/tempo/noticia/2012/03/o-paciente-de-r-800-mil.html $>$. Acesso em: 13 de julho de 2015.
} 
A decisão em exame, que cuida de fornecer o Soliris a um paciente, é apenas um dos casos em que o princípio da isonomia fica seriamente abalado. Não são muitos os pacientes que foram ao Judiciário em busca do Soliris, medicamento de altíssimo custo fornecido por um laboratório estrangeiro apenas, ao preço que lhe convenha. Todavia, em que pese saibamos do julgamento de poucos casos envolvendo o fornecimento do Soliris, o fato é que atualmente o SUS gasta aproximadamente mais de um milhão de reais por ano com apenas um paciente, sendo que a Associação Brasileira de HPN - ABHPN afirma existirem mais de 200 (duzentos) casos da doença no país ${ }^{14}$.

A questão a ser colocada diz respeito ao fato de que a decisão sob análise, que já podemos qualificar de uma decisão em que há um evidente protagonismo judicial, em nome da efetividade do direito fundamental à saúde, afronta o princípio da igualdade, pois, concretamente, enquanto hoje o Estado brasileiro gasta mais de $\mathrm{R} \$ 1.200 .000,00$ (um milhão e duzentos mil reais) por ano com um paciente que teve direito judicialmente reconhecido ao Soliris ${ }^{15}$, no país todo faltam medicamentos básicos, leitos hospitalares, UTI’s, ambulâncias, não sendo difícil lermos notícias de pacientes sendo atendidos dentro de banheiros de unidades hospitalares públicas.

E, embora não sejam muitos os casos que chegaram ao Judiciário sobre a enfermidade que acomete o autor da demanda em que foi concedida a antecipação de tutela sob apreço, a fundamentação dessa decisão é uma decisão do STF (que até mesmo à luz do NCPC não tem força vinculante obrigatória), o que poderia aparentemente induzir-nos a pensar que o respeito pelo que numa acepção tradicional é compreendido como precedente, ou seja, por um pronunciamento judicial proferido anteriormente e que, no futuro, poderá ser relevante para o julgamento de novos casos análogos ou idênticos, preservaria a integridade do Direito e afastaria o adjetivo de ativista da interlocutória. Todavia, o pronunciamento judicial anterior utilizado também foi fundamentado diretamente em norma constitucional que trata do direito fundamental à saúde, a fim de permitir a concessão do medicamento mais caro do mundo ao paciente do SUS. Aqui o respeito ao que inicial e tradicionalmente ficou conhecido como sendo precedente não se prestou a afastar o ativismo judicial, pois, além de fundada diretamente em norma constitucional, a decisão do STF também suprimiu a lei em vigor.

Considerando as normas de direitos fundamentais como princípios, tal como dizem Mendes, Coelho e Branco (2000), a direta aplicação da norma jusfundamental do direito à saúde na decisão examinada evidenciou que a concessão do medicamento mais caro do mundo a um paciente do SUS, pelo menos na decisão analisada, não se encontra alcançada pelas ideias de limites ou de restrição do direito fundamental à saúde, fato esse que segue presente em outros pronunciamentos judiciais análogos. Assim, pode o SUS ser compelido judicialmente a dar o medicamento mais caro do mundo a paciente do serviço público de saúde.

É, a esta altura, bom lembrarmos que os direitos sociais, tal como ocorre com o direito à saúde, não são apenas normativos, eles têm também um sentido promocional, prospectivo, sendo que isso altera a função do Judiciário, porque perante os direitos sociais não cumpre julgar no sentido de estabelecer o certo ou o errado com base na lei. Então, diante dos direitos sociais não falamos em responsabilidade condicional do juiz politicamente neutralizado, pois estamos diante da responsabilidade finalística do juiz (FERRAZ JÚNIOR, 2000).

\footnotetext{
${ }^{14}$ Fonte: http://www.grupemef.com.br/noticias_completa.php?not_id=589.

${ }^{15}$ O Estado de São Paulo, até 2011, tinha sido condenado a custear o Soliris a 34 (trinta e quatro) pacientes. Portanto, hoje, se não modificadas as decisões judiciais que concederam o medicamento, esse ente federativo necessita gastar com os 34 (trinta e quatro) pacientes $\mathrm{R} \$ 40.800 .000,00$ (quarenta milhões e oitocentos mil reais). Fonte: Fonte: Revista Época, 16/03/2012. Disponível em <http://revistaepoca.globo.com/tempo/noticia/2012/03/o-paciente-de-r-

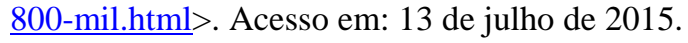


Ferraz Júnior (2000) trata do "sentido promocional prospectivo" dos direitos sociais, ao dizer que:

altera a função do Poder Judiciário, ao qual, perante eles ou perante a sua violação, não cumpre apenas julgar no sentido de estabelecer o certo e o errado com base na lei (responsabilidade condicional do juiz politicamente neutralizado), mas também e sobretudo examinar se o exercício discricionário do poder de legislar conduz à concretização dos resultados objetivados (responsabilidade finalística do juiz que, de certa forma, o repolitiza). (...) Altera-se, do mesmo modo, a posição do juiz, cuja neutralidade é afetada, ao ver-se ele posto diante de uma co-responsabilidade no sentido de uma exigência de ação corretiva de desvios na consecução das finalidades a serem atingidas por uma política legislativa. Tal responsabilidade, que, pela clássica divisão dos poderes cabia exclusivamente ao Legislativo e Executivo, passa a ser imputada também à Justiça. (FERRAZ JÚNIOR, 2000, p. 345)

É isso, aliás, que vemos na decisão analisada, o sentido promocional do direito à saúde. E, mais do que isso, o que tem ocorrido é que um direito social previsto no art. $6^{\circ}$ e ainda nos arts. 196 e seguintes da Constituição da República vem sendo tratado pelo Judiciário brasileiro basicamente como direito individual, graças à presença de fatores no ordenamento jurídico que abrem a possibilidade para que decisões judiciais sejam ativistas ou, melhor dizendo, para que exista um protagonismo judicial.

Apesar de ser um conceito fugido, conforme ensina Gonet (2011), é também possível verificarmos ativismo judicial, quando uma decisão vai de encontro à lei e invoca outros princípios ou outros fundamentos do Direito para superar a lei, o que se materializa num esforço do julgador em não aplicar o que o legislador determina. Além disso, podemos verificar a ocorrência de ativismo, quando o Judiciário assume o papel de promover avanços sociais diante de impasses políticos, sendo que na decisão analisada podem ser verificadas ambas as circunstâncias.

Quando o Judiciário interfere em alguma medida na execução de políticas públicas, sobretudo quando as cria ou desconsidera as que existem, quando supera decisões tomadas pelos canais político-representativos ou quando supre omissões dos poderes políticos que ofendem direitos fundamentais, há ativismo também, o qual pode ser conservador ou progressista. E, no caso da decisão apreciada, sem tratar da política pública referente a medicamentos, o juiz, na defesa de direito fundamental à saúde, interferiu na mencionada política pública, tudo em nome da efetividade do direito fundamental à saúde encarado como direito individual, o que também é uma postura ativista ou, mais propriamente, configura um protagonismo judicial.

É forçoso reconhecermos, também, que o contexto em que decisões como a ora analisada podem ser proferidas caracteriza-se pela existência de uma Constituição abrangente, como dito antes, e autoaplicável no campo dos direitos fundamentais. É, pois em nome da efetivação de direitos fundamentais, que decisões ativistas como a presentemente discutida podem ser proferidas.

Quanto à fundamentação da decisão interlocutória analisada feita com base em pronunciamento judicial anterior, vale a mesma consideração que fizemos quando da apreciação da aplicação das normas de direito processual destinadas a possibilitar a concessão da antecipação de tutela satisfativa. Daí porque podemos afirmar que decisões despossuídas de fundamentação consistente tendem a ser ativistas.

Ainda sobre o ativismo, Barroso (2012) diferencia judicialização de ativismo. Segundo ele, a primeira significa que questões de grande repercussão política e social estão sendo levadas ao Judiciário, ao invés de serem tratadas pelo Legislativo, e que, no contexto brasileiro, é um fato absolutamente decorrente do modelo constitucional. Já o ativismo tem relação com uma 
participação mais densa do Judiciário na concretização e valores e de fins constitucionais, com maior interferência no espaço em que atuam o Executivo e o Legislativo.

Desse modo, embora judicialização - que não é um exercício deliberado de vontade política - e ativismo sejam, nas suas palavras, primos, eles possuem causas distintas, sendo que as causas do primeiro são a redemocratização do Brasil, que atinge seu ápice com a Constituição de 1988, a constitucionalização abrangente e o sistema de controle de constitucionalidade brasileiro (BARROSO, 2012).

O ativismo, por sua vez, ocorre quando a Constituição é aplicada diretamente a situações que não estão expressamente previstas em seu texto, independentemente da atuação do legislador ordinário; quando ocorre a declaração de inconstitucionalidade das leis com critérios menos rígidos do que aqueles relacionados à clarividente violação da Constituição, e, ainda, quando o Judiciário impõe condutas ou abstenções ao poder público, sobretudo ao se tratar de políticas públicas (BARROSO, 2012).

Havemos de reconhecer, por tudo que foi dito, a despeito do conceito efetivamente fugidio de ativismo (GONET, 2011), que a decisão interlocutória apreciada é uma decisão ativista ou, melhor dizendo, que nela está evidente um protagonismo judicial.

\section{CONCLUSÃO}

Por meio da análise da decisão interlocutória que concedeu o medicamento Soliris em antecipação da tutela satisfativa ao autor da demanda cível ajuizada perante a Justiça Federal no Acre, foi possível detectarmos na decisão em comento a presença de alguns dos fatores que indicam estarmos diante de uma decisão ativista.

De mesmo modo, a análise da decisão possibilita-nos, partindo do caso específico, fazer algumas constatações de natureza generalizante.

Assim, além da constatação de que estamos diante de uma decisão ativista ou, melhor ainda, de um protagonismo judicial, precisamos ter em mente o tamanho do problema que atinge a saúde pública no Brasil.

Se é certo que o Judiciário, quando provocado, pode, no sistema constitucional brasileiro, ser chamado a efetivar direitos fundamentais, cabem, de imediato, pelo menos duas indagações. Primeiro, como podemos assegurar a integralidade do direito à saúde sem desprezarmos o fato de que tal integralidade deve implicar também no zelo pela equidade no acesso aos serviços e às ações de saúde, tendo em consideração que o direito à saúde é essencialmente coletivo ${ }^{16}$ ? Segundo, em que contexto problemas da dimensão dos que atingem a efetividade do direito à saúde ocorrem no Brasil, onde a intensa judicialização da saúde é uma realidade?

Não estamos a caminho da solução desses gigantescos problemas, e isso hoje é certo, todavia, é igualmente certo que, se por um lado nada há de anormal, ilícito ou inconstitucional na judicialização em tese da saúde, que decorre dos modelos de Estado e de tripartição de poderes adotados no Brasil, por outro lado decisões ativistas envolvendo o direito à saúde têm evidenciado algo que dispensa o uso da técnica para ser reconhecido, pois até mesmo na experiência diária de todos que devem lidar com orçamento, ainda que doméstico, é sabido que não há nada que possa prosperar sendo mal administrado pelo Executivo, mal pensado pelo Legislativo e administrado de modo fragmentado pelo Judiciário.

O SUS, para bem funcionar, exige urgente comunhão de esforços de todos os entes estatais e da sociedade brasileira no sentido de concretizar o direito social à saúde respeitando a isonomia, o que implica especialmente na garantia da equidade no acesso a tratamentos e a

\footnotetext{
${ }^{16}$ Atualmente aguardam julgamento no STF dois Recursos Extraordinários importantíssimos para o debate acerca do direito à saúde, sua judicialização, o fornecimento de medicamento não registrado na Anvisa (RE 657718) e o fornecimento de medicamento de alto custo (RE 566471).
} 
medicamentos, sem falarmos no fato de que o SUS foi desenhado sob o viés da prevenção, o que, por si só, demanda outras discussões até mesmo sobre as fontes de financiamento e a prioridade das ações preventivas.

Segundo Pivetta (2013), inclusive, um SUS devidamente estruturado seria capaz de solucionar ou de reduzir de modo bastante considerável a judicialização do direito à saúde, além de fazer com que, de modo inclusivo, a vida de milhões de brasileiros pudesse tornar-se mais digna.

Aliás, se a resposta àquela primeira pergunta não é exata e, provavelmente perpassa a construção de consensos sobre o direito à saúde e a questão da integralidade de sua assistência, a resposta à segunda indagação parece-nos menos impossível de ser dada neste momento. $\mathrm{O}$ contexto em que decisões ativistas tal como a que foi analisada vem sendo proferidas é um contexto de séria crise, em que, diante da ineficiência do SUS no atendimento de qualidade à maioria dos brasileiros, e aqui estamos nos referindo à assistência básica à saúde, os artigos $6^{\circ} \mathrm{e}$ 196 da Constituição vêm prestando-se a fundamentar decisões judiciais que, se não garantem a saúde de todos na melhor medida possível, salvam, na mais esperançosa hipótese, aquele que por sorte buscou a defesa de sua saúde no Judiciário.

E é bom que tenhamos em mente, que tal contexto tem como principal característica a promessa constitucional de que todos têm direito à saúde, e que para isso a assistência deve ser integral. No caso, o que verificamos é uma permanente tensão entre a promessa de saúde plena e a escassez de recursos, a ineficiência da gestão do SUS, a corrupção e, nos últimos anos, a interferência fragmentada do Judiciário no Sistema Único de Saúde, sob o fundamento da efetividade do direito fundamental à saúde, sem considerar, por exemplo, as políticas públicas de fornecimento de medicamentos existentes.

Fica claro, portanto, em que pese tenhamos realizado a análise de uma decisão apenas, que deve a sociedade brasileira debater e definir consensualmente o que quer e pode financiar para assegurar o direito à saúde de todos, de tal modo que as normas a partir desse consenso formadas deverão realmente valer para todos.

Do contrário, somente para duzentos pacientes portadores de HPN, o SUS brasileiro deverá gastar anualmente, a quantia aproximada de $\mathrm{R} \$ 240.000 .000,00$ (duzentos e quarenta milhões de reais), sem qualquer chance de cura da enfermidade, apenas com a dispensação do medicamento mais caro do mundo.

\section{REFERENCIAS}

ASENSI, Felipe. A judicialização da saúde no Brasil. Revista Justiça e Cidadania, ed. 155, 2013. Disponível em: 〈http://www.editorajc.com.br/a-judicializacao-da-saude-no-brasil//>. Acesso em; 02 de setembro de 2017.

ASENSI, Felipe. O judicial e o extrajudicial: Ministério Público e direito à saúde no Brasil. Revista de Direito Administrativo \& Constitucional, ano 3, n. 11, (jan/mar. 2003), Belo Horizonte: Fórum, 2003.

BARROSO, Luís Roberto. Judicialização, Ativismo Judicial e Legitimidade Democrática. (Syn)Thesis. Vol. 5, n. 1, Rio de Janeiro: 2012. Disponível em: <file:///C:/Users/Marques/Documents/DOUTRINA\%20Barroso\%20e\%20ativismo\%20completo. pdf>. Acesso em: 14 de julho de 2015.

BERMUDEZ, J. A. Z. Indústria Farmacêutica, Estado e Sociedade. São Paulo: Hucitec/ Sobravime, 1995. 
BRANCO, Paulo Gustavo Gonet. Em busca de um conceito fugidio - O ativismo judicial. In FELLET, André Luiz Fernandes; PAULA, Daniel Giotti de e NOVELINO, Marcelo (org.); As novas faces do ativismo judicial, Editora Jus Podivum, 2011.

BRANCO, Paulo Gustavo Gonet; COELHO, Inocêncio Mártires; MENDES, Gilmar Ferreira. Curso de Direito Constitucional. São Paulo: Saraiva, 2009.

BRASIL. Ministério da Saúde. Secretaria de Ciência, Tecnologia e Insumos Estratégicos. Departamento de Assistência Farmacêutica e Insumos Estratégicos. Da excepcionalidade às linhas de cuidado: o Componente Especializado da Assistência Farmacêutica. Série B. Textos Básicos da Saúde. Brasília, 2010. Disponível em: 〈http://bvsms.saude.gov.br/bvs/publicacoes/excepcionalidade_linhas_cuidado_ceaf.pdf $>$. Acesso em 10 de julho de 2015 .

BRASIL. Ministério da Saúde. Assistência Farmacêutica. 2014. Disponível em: <http://portalsaude.saude.gov.br/index.php/o-ministerio/principal/leia-mais-o-ministerio/470sctie-raiz/daf-raiz/daf/12-daf/12125-assistencia-farmaceutica>. Acesso em 10 de julho de 2015.

CARIAS, Claudia Mezleveckas et ali. Medicamentos de dispensação excepcional: histórico e gastos do Ministério da Saúde do Brasil. Rev. Saúde Pública, vol. 45, n. 2, São Paulo Apr. 2011. Disponível em: $\quad$ http://www.scielo.br/scielo.php?script=sci_arttext\&pid=S003489102011000200001>. Acesso em: 14 de julho de 2015.

DALlARI, Sueli Gandolfi. O direito à saúde. Rev. Saúde Pública, São Paulo, v. 22, n. 1, fev. 1988.

DIDIER JUNIOR, Fredie; BRAGA, Paula Sarno; OLIVEIRA, Rafael Alexandria de.Curso de Direito Processual Civil: Teoria da Prova, Direito Probatório, Decisão e Tutela Provisória. 10 ${ }^{a}$ edição, Salvador: Ed. Jus Podivm, 2015, v. 2.

FERRAZ, Antônio A. M. de Camargo \& BENJAMIN, Antônio H. de Vasconcelos e. O conceito de "relevância pública" na Constituição Federal. In: DALLARI, Sueli (Org.). O conceito constitucional de relevância pública. Brasília: Organização Pan-americana da Saúde, 1992.

FERRAZ JÚNIOR, Tercio Sampaio. O Judiciário frente à divisão dos poderes. In: Anuário dos Cursos de Pós-Graduação em Direito da UFPE. Recife, n. 11, 2000. p. 345-359.

FREITAS FILHO, Roberto; LIMA, Thalita Moraes. Metodologia de Análise de Decisões. Trabalho apresentado no XIX Encontro Nacional do CONPEDI. Fortaleza, jun 2010. Disponível em: 〈http://www.publicacoesacademicas.uniceub.br/index.php/jus/article/view/1206>. Acesso em 12 de junho de 2015.

FRISCHEISEN, Luiza Cristina Fonseca. Políticas públicas. A responsabilidade do administrador e o Ministério Público. São Paulo: Max Limonad, 2000.

MENDES, Gilmar Ferreira; COELHO, Inocêncio Mártires; BRANCO, Paulo Gustavo Gonet. Hermenêutica Constitucional e Direitos Fundamentais. Brasília: Brasília Jurídica, 2000. 
MOSEGUI, G. B. G. et al. Avaliação da qualidade do uso de medicamentos em idosos. Rev. de Saúde Pública, 33(5): 444-457.1999.

OLIVEIRA, Euglébia Andrade; LABRA, Maria Eliana; BERMUDEZ, Jorge. A produção pública de medicamentos no Brasil: uma visão geral. Cad. Saúde Pública. 2006; 22(11): 2379-89.

PIVETTA. Saulo Lindorfer. Direito Fundamental à Saúde: regime jurídico-constitucional, políticas públicas e controle judicial. Defesa em: 15.03.2013. Dissertação (Mestrado) - Programa de Pós-Graduação em Direito da Universidade Federal do Paraná: Curitiba, 2013.

SÁNCHEZ, José Acosta. Formación de la Constitución y Jurisdicción Constitucional. Madrid: Tecnos, 1988.

SCHLESINGER JR, Arthur M. The Supreme Court: 1947, in Fortune, Jan. 1947.

SCHWARTZ, Germano. O tratamento jurídico do risco no direito à saúde. Porto Alegre: Livraria do Advogado, 2004.

TALAMINI, Eduardo. O que são “precedentes vinculantes" no CPC de 2015. 2016. Disponível em: $\quad\langle$ http://www.migalhas.com.br/dePeso/16,MI236392,31047-

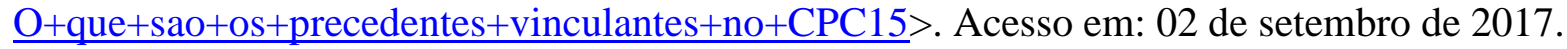

WANG, Daniel Wei Liang. Courts as healthcare policy-makers: the problem, the responses to the problem and problems in the responses. São Paulo Law School of Fundação Getúlio Vargas Direito GV, 2013. Disponível em <file:///C:/Users/Marques/Downloads/SSRNid2335145\%20(1).pdf $>$. Acesso em 12 de julho de 2015. 